\title{
The Transformative Potential of the Scholarship of Teaching
}

\section{ABSTRACT}

In discussing personal stances professionals might take towards their practice, Hoyle contrasts two orientations that can be placed at the ends of a continuum. The first pole, the so-called 'restricted' stance, is characterised by teachers relying principally on experience and intuition, and focusing on daily classroom practicalities. The second pole, the so-called 'extended' stance, is characterised by teachers valuing the theory underpinning practice, taking a more intellectual and rationally-based approach and holding a broader vision of education. I argue in this article that the scholarship of teaching and learning, when enacted in its 'extended' form, would be distinguished by two important features: a wider sense of what counts as relevant theory and a broader vision of what university teaching, and the education it is there to support, is for. The argument is built around three additional claims: (1) engaging in the scholarship of teaching and learning authentically means to be motivated by a commitment to serve the important interests of students; (2) what is in the important interests of students is their own development towards greater authenticity; (3) promoting students' authenticity has implications not just for students' academic learning and personal flourishing but also for creating greater social justice in the world. These claims are substantiated by reference to theories of "authenticity" and learning as well as the capabilities approach to human development.

\section{KEY WORDS}

SOTL and social justice, transformative potential, professionalism

\section{BEYOND DISCIPLINARITY: TOWARDS A COMMON RATIONALE FOR UNIVERSITY TEACHING}

The connections between subject matter knowledge and knowledge of pedagogy, epitomised in the notion of pedagogical content knowledge (Shulman, 1987), led to the Scholarship of Teaching and Learning (SoTL) being closely associated with the disciplines (e.g., Healey, 2000; Huber \& Morreale, 2002). Boyer (1990) had sensibly argued that "those who teach must, above all, be well informed, and steeped in the knowledge of their fields" and "build bridges between their understanding and the student's learning" (p. 23). Palmer (1998), too, suggests that good teachers succeed in bringing stu- 
dents into "the circle of practice" in their disciplines, "into its version of the community of truth" (p. 122) so they can practice the discipline's core ideas, concepts and ways of functioning. Meyer and Land (2006) proposed that a defining feature of learning at the university level is students acquiring a grasp of the fundamental ideas underpinning the subject or discipline they are studying, its so-called threshold concepts, as without a good understanding of these the deeper meaning of the subject will remain concealed from them. Making a similar point, Entwistle (2009) referred to the inner logic of the subject and its corresponding pedagogy.

While part of the scholarship of teaching and learning then necessarily must be discipline-specific, some authors have observed that a purely disciplinary perspective could be a potential limitation to the academics' critical engagement with teaching and learning (e.g., Nicholls, 2005; Weimer, 1997). Perhaps in response to such concerns, Shulman (2005) argued that our academic communities become enriched as the pedagogical practices distinctive to particular disciplines (or professional subjects) are shared across disciplinary boundaries and Huber and Morreale (2002) suggested to trade not only pedagogical practices but also the questions we characteristically ask about them in certain disciplines and the methods employed in their investigations. This call for crossdisciplinarity in SoTL I would like to explore a little further, focusing on notions of academic community and identity.

Although disciplinary affiliation has been shown to continue to play a central role in academics' sense of identity (e.g., Fanghanel, 2011; Henkel, 2005; Kreber, 2010), Brookfield (1990) encourages university teachers to look beyond their own disciplines and see themselves also as members of a larger community of teachers engaged in a common purpose. This, he maintains, ought to be an essential aspect of the academic's professional identity. In his own words:

If college teachers define themselves only as content or skill experts within some narrowly restricted domain, they effectively cut themselves off from the broader identity as change agents involved in helping students shape the world they inhabit. What is needed to counter this tendency towards isolated separatism is an underlying rationale for college teaching. This rationale, although it would acknowledge the importance of specialist curricula and expertise, would go beyond these to unite college teachers who work in very divergent contexts in the pursuit of shared purposes. (Brookfield, 1990, p. 17-18)

McLean (2006) also highlights the importance of academics reaching some agreement on what university teaching is for, arguing:

... individual performance is not enough for genuine pedagogic improvements in universities. What is essential is that relevant actors come to agreement about what counts as good pedagogy, for what purposes and what is to be done to make it happen. ( $p .126)$

However, the question that still needs to be answered is, "What might qualify as a common rationale, one that would unite university teachers in the pursuit of shared purposes and thus serve both as a beacon and as a basis of academic identity and the improvement of teaching?" Brookfield seems to imply that the purpose of university teaching is to help 
students "shape the world they inhabit" (p. 17), but more needs to be said about what this might imply and how students' 'shaping of the world' might contribute not only to their own sense of agency, and perhaps enhanced personal efficacy and advancement, but also to shared goods including greater social justice in the world.

I shall make three claims in this article that are intended to strengthen Brookfield's comment and articulate a common rationale for what we do in SoTL. I will address these claims in turn and substantiate them through reference to relevant theories. In the second part of the article, I will frame my argument around Hoyle's (1975) classic distinction between two models of "teacher professionality" — restricted and extended — which I propose are particularly helpful in advancing our understanding of what engagement in SoTL might entail and what it is all for.

\section{THE THREE CLAIMS}

\section{The first claim: Engaging in the Scholarship of Teaching and Learning authentically means to be motivated by a duty and commitment to serve the important interests of students.}

Our motivations for engaging in SoTL can be explained in at least three ways: a) as a response to an external demand or reward (extrinsic motivation); b) as a response to an internal drive or desire (intrinsic motivation); or c) as a response to a felt sense of duty or commitment to act in the important interests of those we are there to serve. Grimmet and Neufeld (1994), discussing professionalism in the context of school teaching, refer to the third response as an authentic professional motivation. Drawing on Taylor's (1991) communitarian interpretation of the ethical ideal of "authenticity," they suggest that the teachers' professional identities are negotiated not just in response to extrinsic and intrinsic motivations, but also, and importantly, in response to a wider horizon of significance (referring to our socially constructed or community-based values and cultural norms) by which we give meaning to, and enact, our work. At its core, this horizon of significance is a shared sense of duty and commitment to act in the important interests of students .

While the purposes of higher education continue to be heavily contested (e.g., Barnett, 1990; Collini, 2012; Furlong \& Cartmel, 2009), one observes among commentators on higher education teaching nonetheless considerable agreement with this first claim (e.g., Brookfield, 2005; hooks, 1998; Elton, 2000). The American social critic and educator bell hooks (2003), for example, suggests that the purpose of teachers is to serve the needs of students. Similarly, Lewis Elton (2000), a British physicist turned educator and researcher of education, argues that teachers have a duty towards students. Do Elton and hooks mean that teachers should respond uncritically to students' expectations, wishes and demands? This is unlikely, given that experienced teachers know that acting in the students' interests may at times involve teachers intentionally not meeting the students' expressed needs (Brookfield, 2005). What Elton and hooks seem to be saying instead is that, at the most fundamental level, the teacher's service or duty is to do what is educationally desirable, and, for this reason, is in the students' important interests (Grimmet \& Neufeld, 1994). However, it is not always made clear how the students' important interests are to be identified and defined. This is where the second claim comes into play. 


\section{The Second Claim: What is in the Important Interests of Students is Their Own Growth Towards Greater Authenticity.}

Why should this claim be the case? I propose that a justification can be found in philosophical literature that is chiefly concerned with highlighting those aspects of our existence that are distinctly human qualities or, by extension, "human interests" (e.g., Freire, 1971; Heidegger, 1962; Habermas, 1971; Nussbaum, 2000, 2011; Nussbaum \& Sen, 1993). Human interests arise from an experience of fundamental needs that must be satisfied for humans to flourish. Heidegger (1962) saw the distinctiveness of human existence in our potential openness to our own particular possibilities. Separating from a state of unawareness of our deepest inner motives he saw as the essence of moving closer to our full potential of (human) being. Habermas (1971) identified emancipation and self-development as a fundamental human interest (along with technical and practical interests). Similar arguments were made by Freire (1971), who showed that the most important learning involves a transformation in consciousness. Proponents of the capabilities approach to human development recognise that being able to choose a life one has reason to value is a fundamental human interest (Nussbaum \& Sen, 1993; Nussbaum, 2000, 2011). Note that "capabilities," as employed by Nussbaum and Sen and others concerned with human development and social justice, are not just skills or competences but instead opportunities for human functioning that enable a fully human and dignified life.

Drawing on the above philosophers' observations, I propose that what is ultimately in the important interests of students is their own flourishing or striving for authenticity. If we accepted this premise we could furthermore conclude that serving the important interests of students, or promoting their fundamental need for authenticity through higher education teaching, is a moral obligation and hence a social justice issue. Now, of course, another question begs to be answered: What is meant by authenticity?

To begin with, let us be clear that an emphasis on the philosophical notion of authenticity does not deny the importance of academic learning of the subject matter. Much has been written about the importance of authentic pedagogy and authentic assessment in the support of students' academic learning (e.g., Neumann, King \& Carmichael, 2007; Herrington, Oliver \& Reeves, 2003; Svinicki, 2005). However, it is helpful to distinguish a being perspective on authenticity from a correspondence perspective (Splitter, 2009), the latter being chiefly concerned with how to make learning tasks correspond most closely to problems students might encounter in the "real world", or those tackled by actual scientists or scholars in the field, and how to promote students' intellectual mastery of these learning tasks (e.g., Neumann, Marks, \& Gamoran, 1996). Though very different, the being and correspondence perspectives are not altogether incompatible. Promoting the authenticity of students implies helping students realise the importance of learning for themselves (Entwistle, 2009; Entwistle \& McCune, 2009) and grasping a subject in their own way (Kreber, 2009). For this to happen, the subject needs to be perceived as meaningful and relevant so that students are able to make connections between what they are learning and their personal lives (see also Palmer, 1998). However, authenticity also has more profound connotations. Students who grow into their authenticity do not only come to know more, but they come to know differently than they did before. What does this mean? 
Over the past several years, universities have begun to emphasise the need for students to achieve so-called 'generic graduate attributes' (Barrie, 2007; Hounsell, 2011). Many lists of such attributes have been generated, typically including knowledge and skills needed for employability. However, such lists increasingly also include items such as: a capacity for ethical, social and professional understanding; teamwork and leadership; global citizenship, and so forth. Although the graduate attribute literature characteristically employs the language of doing (i.e., what graduates should be able to do with the knowledge acquired) rather than being (i.e., an emphasis on who the students are becoming), and thus usually does make use of the word "authenticity", we nonetheless witness today a greater acceptance of the proposition that higher education should support students in developing not just intellectually, or academically, but also personally and interpersonally (see also Baxter Magolda, 1999).

Moving towards greater authenticity entails that students develop an awareness of their own unique possibilities (Heidegger, 1962), including recognizing how certain beliefs, habits and expectations they have acquired might have limited their choices up to now (Freire, 1971; Mezirow, 1991). Barnett (2007) argues that students should have the opportunity to become "disencumbered" from other voices. The existential and critical perspectives on authenticity, therefore, suggest that fostering students' authenticity involves encouraging students to engage in critical reflection. In addition, and as suggested by the communitarian perspective (Taylor, 1991), fostering authenticity means helping students understand themselves as members of a wider social community towards which they feel a responsibility (Kreber, 2013).

Baxter Magolda $(1999,2009)$ argues that an important purpose of higher education is to promote the student's self-authorship, which she defines as an intellectual, personal and relational maturity. Relational maturity involves an "understanding of and commitment to one's own interests in interaction with understanding and commitment to the interests of others" (Baxter Magolda, 2009, p.144). Self-authorship, or as we might want to say, authenticity, then entails the ability to recognise others' points of view without being determined by these others. But self-authorship, or authenticity, also requires acting ethically, to have an understanding and commitment to the interests of others. To feel such a commitment towards the interests of others means to recognise also others' needs for authenticity. Similar considerations led Bonnett and Cuypers (2003) to conclude that:

Properly conceived, student authenticity must remain a central concern of education because of its internal relationship with personal significance in learning, moral education, interpersonal understanding, and education for democratic citizenship. It is also, of course, integral to what it is to be a full human being - constituting as it does much of what is meant by human integrity and dignity. ( $p$. 339)

This discussion leads directly to the third claim.

\section{The Third Claim: Promoting Students' Authenticity has Implications not just for Students' Academic Learning and Personal Flourishing but also for Creating Greater Social Justice in the World.}

This claim implies that students strive not only towards their own authenticity but recognise their mutual interdependence and the need to support others' in becoming 
authentic. The reciprocal nature of authenticity has been noted by several scholars (e.g., Brookfield, 2005; Buber, 1958; Eagleton, 2007; Nixon, 2008; Nussbaum, 2004; Taylor, 1991). Nixon (2008) helpfully draws attention to the distinction between the innerdirected and outer-directed aspects of authenticity. When inner-directed, Nixon suggests, authenticity takes on the form of "courage". Courage is required for seeking to assert one's own claims to recognition. When outer-directed, authenticity is expressed as "compassion". Compassion is required for seeking to assert the claims of others to recognition.

As noted by Nussbaum (2004), our capacity for compassion for those in need is based on three judgments we make: firstly, we understand the situation of these others as serious (which involves being able to imagine a situation from the perspective of someone else); secondly, we infer that they are not to blame for the situation they are in; and, thirdly, and significantly, we recognise their vulnerability as a distinct possibility for ourselves. This last judgment implies that we see others as our fellow human beings who are important to our own flourishing or authenticity.

If we accept the claims made by Nixon and Nussbaum we can also assert that, by looking out for one another on the basis of compassion, we support one another's authenticity. Authenticity thus construed is reciprocal; we work towards our own flourishing, or authenticity, by helping others with their flourishing (e.g., Brookfield, 2005; Buber, 1958; Eagleton, 2007; Nixon, 2008; Nussbaum, 2004; Taylor, 1991).

"Capabilities," as understood by Nussbaum and Sen (1993) as opportunities for human functioning, make authenticity possible. Drawing directly on the work of Martha Nussbaum (2000, 2011), Walker (2006) suggested that higher education should foster capabilities such as "Practical reason; Educational resilience; Knowledge and imagination; Learning dispositions; Social relations and integrity; Respect, dignity and recognition; and Emotional integrity" (p. 127). Fostering these capabilities would fulfil two purposes. Firstly, the students' authenticity is enabled in that students, who enter university with diverse backgrounds, aspirations and unequal opportunities, are supported in achieving their potential through higher education. Secondly, fostering these capabilities contributes to a more just and sustainable society as the students employ the capabilities they were afforded through higher education for the sake of promoting the same capabilities among wider society, thereby supporting the authenticity of others.

One might argue that this can happen through volunteering in the community, through political engagement and social action, or simply through the various decisions graduates make in their personal lives. However, an important implication arises in particular for graduates from professional subjects, such as engineering, law, health care, accounting, social work and so forth. Fostering the above capabilities in students on professional programmes could have a profound impact on how they engage in their work context after graduation (e.g., Nixon, 2011; Walker, 2010; Walker \& McLean, 2013), thereby supporting the authenticity of those they serve. A decade ago, Cortese (2003) observed that "it is the people coming out of the world's best colleges and universities that are leading us down the current unhealthy, inequitable, and unsustainable path", urging universities to teach "the awareness, knowledge, skills and values needed to create a just and sustainable future" (p.17). This call for authentic and socially responsible professionals with an inner disposition to act in the interests of the "public good," rather than according to self-interest or in exclusive compliance with external demands or directives, continues to be critical. 


\section{SUMMING UP}

Given the strong emphasis on disciplinarity in the scholarship of teaching and learning, I took as a starting point for this discussion Brookfield's (1990) observation that academics ought to define themselves not exclusively as discipline-experts but also in relation to the common purpose of "helping students shape the world they inhabit" (p. 17). I then introduced and defended three interrelated claims in support of this statement. I argued, firstly, that engaging in the scholarship of teaching and learning authentically means to be motivated by a duty and commitment to serve the important interests of students; secondly, that it is in the important interests of students that they move towards greater authenticity; and thirdly, that promoting students' authenticity has implications not just for students' academic learning and personal flourishing but also for creating greater social justice in the world. I suggested that this third claim becomes an issue in particular in relation to students in professional subjects.

In the second part of this article, my intent now is to show how the arguments presented so far are compatible with an extended form of professionality (Hoyle, 1975). I propose that the Scholarship of Teaching and Learning is enhanced if enacted in this "extended" form. An extended form of professionality requires a wider sense of what counts as relevant theory in SoTL and a broader vision of what university teaching, and the education it is there to support, is for.

\section{The Scholarship of Teaching and Learning as an Extended Form of Teacher Professionality}

Hoyle (1975) offered the classic distinction between an extended and a restricted model of professionality. Evans (2002) defined Hoyle's two models as "an ideologically-, attitudinally-, intellectually-, and epistemologically-based stance on the part of an individual, in relation to the practice of the profession to which $\mathrm{s} /$ he belongs, and which influences her/his professional practice" (pp. 6-7) and later interpreted the two models as the ends of a continuum (Evans, 2008). At the one end, there is the restricted professional, characterised by teachers relying principally on experience and intuition, and focusing on daily classroom practicalities. At the other end of the continuum, there is the extended professional, characterised by teachers valuing the theory underpinning practice, taking a more intellectual and rationally-based approach and holding a broader vision of education.

While in one sense present conceptions of SoTL have encouraged engagement with teaching that reflects the extended professionality pole of the continuum, I shall argue that this has not been achieved in another sense. An extended sense of professionality in SoTL is distinguished by two important features: a wider sense of what counts as relevant theory and a broader vision of university education.

\section{Relevant Theory in the Scholarship of Teaching and Learning}

The importance of theory in SoTL has been highlighted by several commentators (e.g., Trigwell, Martin, Benjamin \& Prosser, 2000; Roxa, Olsson \& Martensson, 2008) but there is little agreement on which theories are relevant and what is the role and nature of theory in this work (Hutchings, Huber \& Ciccone, 2011; Huber \& Hutchings, 2008; Hutchings, 2007). 
Despite the on-going theory debate one can observe a strong tendency for the SoTL to be interpreted as empirical inquiries into the relationship between instructional strategy and the students' learning of the material taught. Implicitly or explicitly, these "what works inquiries" draw on psychological theories of student learning which, so far, have arguably had the strongest influence on SoTL. This may not be surprising, as understanding how students learn is considered an essential, by some, the most fundamental, aspect of becoming a good teacher. And clearly, empirical "what works inquiries" exploring how students learn the subject matter that is distinctive to our disciplines, how they, for example, work through bottleneck concepts or troublesome knowledge in these disciplines, undoubtedly represents vital forms of engagement in SoTL; and some of the established theories these studies are based on (e.g., Perkins, 2005; Meyer \& Land, 2006) are important sources of knowledge informing such scholarship. Psychological theories on student learning and "what works inquiries" are important; nonetheless, studying the cognitive challenges students experience in the learning of subject matter without also paying attention to the disparate identities and resulting diversity in the challenges and motives experienced by different students, and the unequal opportunities students have to achieve their potential through higher education, may not go far enough if SoTL is to really make a difference in the world. It is for this reason that SoTL would be greatly enhanced if it listened not only to psychologically-based theories of learning and of instructional design but also, in particular, to philosophy, ethics, sociology, anthropology, history and aesthetics. It is in this sense that the scholarship of teaching and learning would also draw and build on the "scholarship of integration" (Cross \& Steadman, 1996). The linkage between the scholarship of integration and the scholarship of teaching and learning can be observed any time we seek to gain new insight into university teaching by integrating knowledge from various academic fields.

The very notion of "theory", it should be acknowledged, has different meanings in different disciplines. Although we can reasonably expect theories to be the outcome of in-depth investigations, these investigations are not necessarily of the empirical kind. In the humanities, theories are often not empirically testable in the way they are in the sciences. Theories in the humanities are largely based on conceptual analysis or ideas rather than research in the traditional sense, where ideas (or rather "hypotheses") require empirical substantiation in order to be deemed valid. Many psychologically-based theories of learning have been generated on the basis of an instrumental rationality, and inquiries into teaching and learning that are informed by these theories likewise typically investigate the relationships between means and ends (i.e., "what works?"). However, as we have seen in the first part of this article, there are also other theories of higher education pedagogy that are grounded in philosophical analysis including, for example, the capabilities approach to higher education pedagogies (e.g., Walker, 2006) or the concept of authentic being (e.g., Barnett, 2004, 2005, 2007; Heidegger, 1962). These can inform teaching and learning in higher education just as usefully as can empirical research findings in the field of psychology. These latter theories do not try to empirically substantiate relationships between variables but seek to pose, and offer answers to, value questions. These theories, therefore, invite us to inquire into questions related to the aims, purposes and underlying values of higher education, thereby thinking about university teaching more broadly, not exclusively in relation to the learning of subject matter. It is this second feature of an extended sense of professionality in teaching that I shall turn to next. 


\section{A BROADER VISION OF UNIVERSITY EDUCATION}

The second feature of an extended sense of professionality is critical engagement with issues beyond one's own classroom practice and disciplinary community (see also Gale, 2009). Scholars of teaching, thus construed, are still concerned with exploring and improving learning within their own classrooms and disciplines, but at the same time they recognise the importance of exploring and deliberating the purposes of university education in our times, of what preparing students for meaningful participation in society means, and what this demands of their own role as academic teachers. Making a related point, Cranton (2011) recently emphasised that the Scholarship of Teaching and Learning "include(s) critical reflection and critical questioning of not only individuals' practice, but also the context within which teaching takes places, that is, the social and institutional norms and expectations that inform and constrain teaching and learning" (p.76, emphasis added). Regardless of the discipline they teach, scholars of teaching recognise that the larger social purposes of university teaching also matter (Brookfield, 1990).

We would assume that students' ability and willingness to engage critically with issues affecting our world are supported by their study of academic disciplines. Nonetheless, the linkages between the students' academic learning in the disciplines and the ways of being that we hope they will develop through participation in higher education can be drawn more explicitly. Likewise concerned with these same linkages, Gale (2009) speaks of a "Level-Three" form of engagement in SoTL which "asks questions about student learning that speak to and influence issues of significance to society, addressing our values writ large, what we need to understand as members of a local, national, global community" (p. 7). Similarly, Leibowitz (2010) advocates a critically engaged SoTL that demonstrates awareness of the socio-political contexts in which we teach. It is in this sense that SoTL draws and builds on the "scholarship of engagement" (Cross \& Steadman, 1996), the latter referring to academic work that is aimed at meeting community needs. Questions around what our students learn, who they become, and how they choose to engage with the world once they graduate from university matter fundamentally to the well-being of our local communities and wider society.

Humanities disciplines would seem best placed to teach the capabilities I discussed in the first part of this article (e.g., Nussbaum, 1997; Walker, 2009) but in line with Gale (2009) and Leibowitz (2010) I argue for a broader vision SoTL, one that applies across disciplines, and where endeavours aimed at improving learning and creating a better world within which to learn and teach, are nested within the larger concern for creating a better world (Kreber, 2013). Walker and McLean (2013) recently demonstrated how important the fostering of such learning is, particularly in professional subjects. Many years ago, Entwistle (1988) distinguished between a narrow and a broad view that teachers may hold about the purposes of education: "The narrow view accepts the existing role of education in reproducing society as it is now, while the broad view may envisage education as a way of changing society" (p. 226). The Scholarship of Teaching and Learning gains in significance when located within this broader perspective.

\section{CONCLUDING COMMENTS}

Enacted as an extended form of professionality, SoTL is informed, not just by psychologically-based theories of learning and instructional design, but by a wider repertoire 
of theories that invite us to ask questions of value and what we are doing this work for. The Scholarship of Teaching and Learning is enhanced when linked to ethical considerations, specifically questions of what we think we are committed to in higher education teaching, what we consider its purpose to be and whether the educational opportunities we presently provide for students are likely to bring about those capabilities and internal qualities that will make a difference to society. Engaging in SoTL authentically means to act in the important interests of students by helping them grow into their own authenticity. Promoting students' authenticity through affording fundamental human capabilities (Nussbaum, 2000, 2011; Walker \& McLean, 2013) also means to act in the important interests of society. In this lies the real transformative potential of the Scholarship of Teaching and Learning. Defining ourselves around such commitments and purposes would be part of developing a new sense of professionalism as academic teachers (e.g., Brookfield, 1990) and hence an integral aspect of the scholarship in which we are engaged.

Carolin Kreber is Professor of Higher Education and Director of the Higher Education Research Group at the University of Edinburgh.

\section{REFERENCES}

Barnett, R. (2007). A will to learn. Buckingham: Society for Research into Higher Education and Open University Press.

Barnett, R. (2005). Recapturing the universal in the university. Educational Philosophy and Theory, 37(6), 785-796.

Barnett, R. (2004). Learning for an unknown future. Higher Education Research and Development, 23(3), 247-260.

Barnett, R. (1990). The idea of higher education. Buckingham,UK: The Society of Research into Higher Education \& open University Press.

Barrie, S. (2007). A conceptual framework for the teaching and learning of generic graduate attributes. Studies in Higher Education, 32(4), 439-458.

Baxter-Magolda, M. (2009). Educating students for self-authorship: Learning partnerships to achieve complex outcomes. In C. Kreber (Ed.), The university and its disciplines (pp. 143156). New York and London: Routledge.

Baxter-Magolda, M. (1999). Creating contexts for learning and self-authorship: Constructivedevelopmental pedagogy. Nashville, TN: Vanderbilt University Press.

Bonnett, M., \& Cuypers, S. (2003). Autonomy and authenticity in education. In N. Blake, P. Smeyers, R. Smith and P. Standish (Eds.), The Blackwell Guide to the Philosophy of Education (pp. 326-340). Blackwell Philosophy Guides. Oxford, UL: Blackwell Publishing.

Boyer, E.L. (1990). Scholarship reconsidered: Priorities of the professoriate. The Carnegie Foundation for the Advancement of Teaching. Princeton, New Jersey: Princeton University Press.

Brookfield, S. (1990). The skilful teacher. San Francisco: Jossey-Bass.

Brookfield, S. (2005). The power of critical theory. Liberating adult learning and teaching. San Francisco: Jossey-Bass.

Buber, M. (1958). I and thou (2nd ed.; R. G. Smith, Trans.). Edinburgh, UK: T. \& T. Clark. 
Collini, S. (2012). What are universities for? London and New York: Penguin Book.

Cortese, A. (2003). The critical role of higher education in creating a sustainable future. Planning for Higher Education, 31(3), 15-22

Cranton, P.A. (2011). A transformative perspective on the scholarship of teaching and learning. Higher Education Research and Development, 30(1), 75-86.

Cross, K. P., \& Steadman, M. H. (1996). Classroom research: Implementing the scholarship of teaching and learning. San Francisco, CA: Jossey-Bass.

Eagleton, T. (2007). The meaning of life. A very short introduction. Oxford, UK: Oxford University Press.

Elton, L. (2000). Turning academics into teachers: A discourse on love. Teaching in Higher Education, 5(2), 257-260.

Entwistle, N. (2009). Teaching for understanding at university: Deep approaches and distinctive ways of thinking. London: Palgrave Macmillan.

Entwistle, N. (1988). Styles of learning and teaching. An integrated outline of educational psychology for students, teachers and lecturers. London: David Fulton Publishers Ltd.

Entwistle, N. J., \& McCune, V. (2009). The disposition to understand for oneself at university and beyond: Learning processes, the will to learn and sensitivity to context. In L-F. Zang \& R. J. Sternberg (Eds.), Perspectives on the nature of intellectual styles (pp. 29-62). New York: Springer.

Evans, L. (2002). Reflective practice in educational research: Developing advanced skills. London: Continuum.

Evans, L. (2008). Professionalism, professionality and the development of education professionals. British Journal of Educational Studies, 56(1), 20-38.

Fanghanel, J. (2011). Being an academic. New York: Routledge.

Freire, P. (1971). Pedagogy of the oppressed. New York: Continuum.

Furlong, A., \& Cartmel, F. (2009). Higher education and social justice. Maidenhead, Berkshire, England: The Society for Research into Higher Education \& Open University Press.

Gale, R. (2009). Asking questions that matter... Asking questions of value. International Journal for the Scholarship of teaching and learning, 3(2). http://academics.georgiasouthern.edu /ijsotl/v3n2/invited_essays/_Gale/index.htm Accessed on 18 August 2012

Grimmet, P., \& Neufeld, J. (Ed.) (1994). Teacher development and the struggle for authenticity. Professional growth and restructuring in the context of change. Teacher College, Columbia University, NY: Teachers College Press.

Habermas, J. (1971). Knowledge and Human Interests. Boston: Beacon Press.

Healey, M. (2000) Developing the scholarship of teaching and learning through the disciplines. Higher Education Research and Development, 19, 169-189.

Heidegger, M. (1962). Being and Time (trans. By John Macquarrie and Edward Robinson. London: SCM Press. (Original work published in 1927)

Henkel, M. (2005). Academic Identity and Autonomy in a Changing Policy Environment, Higher Education, 49(1), 155-76. 
Herrington, J., Oliver, R., \& Reeves, T.C. (2003). Patterns of engagement in authentic online learning environments. Australian Journal of Educational Technology, 19(1), 59-71.

hooks, b. (2003). Teaching community. A pedagogy of hope. New York: Routledge.

Hounsell, D. (2011). Graduates for the 21st Century: Integrating the Enhancement Themes. Synthesis of work of the theme 2010-2011. QAA paper graduate attributes http://www .enhancementthemes.ac.uk/docs/resources/synthesis-of-work-of-the-theme-2010-2011 -end-of-year-report-dai-hounsell.pdf Accessed 18 August 2012

Hoyle, E. (1975). Professionality, professionalism and control in teaching. In V. Houghton et al., (Eds.), Management in Education: The management of organisations and individuals (pp. 314-320). London: Ward Lock Educational in association with Open University Press.

Huber , M., \& Hutchings, P. (2008). Placing theory in the scholarship of teaching and learning. Arts and Humanities in Higher Education, 7, 229-244.

Huber, M., \& Morreale, S.P. (2002). Situating the scholarship of teaching and learning: A crossdisciplinary conversation. In M. Huber and S.P. Morreale (eds), Disciplinary styles in the scholarship of teaching and learning: Exploring common ground (pp. 1-24). Carnegie Foundation for the Advancement of Teaching and The American Association for Higher Education.

Hutchings, P. (2007). Theory: The elephant in the scholarship of teaching and learning room. International Journal for the Scholarship of teaching and learning, 1(1). http://academics .georgiasouthern.edu/ijsotl/2007_v1n1.htm Accessed on 18 August 2012.

Hutchings, P., Huber, M.Y., \& Ciccone, A. (2011). The Scholarship of Teaching and Learning reconsidered: Institutional integration and impact. The Carnegie Foundation for the Advancement of Teaching. San Francisco: Jossey-Bass.

Kreber, C. (2013). Authenticity in and through teaching in higher education: The transformative potential of the scholarship of teaching and learning. London and New York: Routledge.

Kreber, C. (2010). Academics' teacher identities, authenticity and pedagogy. Studies in Higher Education, 35(2), 171-194.

Kreber, C. (2009). Supporting student learning in the context of diversity, complexity and uncertainty. In C. Kreber (Ed.), The University and its disciplines: Teaching and learning within and beyond disciplinary boundaries (pp. 3-19). London, New York: Routledge.

Mezirow, J. (1991). Transformative dimensions of adult learning. San Francisco: Jossey-Bass.

Leibowitz, B. (2010). Towards SOTL as critical engagement: A perspective from the "South". International Journal for the Scholarship of teaching and learning, 4(2). http://academics .georgiasouthern.edu/ijsotl/v4n2/invited_essays/PDFs/_Leibowitz.pdf Accessed on 18 August 2012

McLean, M. (2006). Pedagogy and the university: Critical theory and practice. London \& New York: Continuum Studies in Education.

Meyer, J.H.F., \& Land, R. (2006). Threshold concepts: An introduction. In J.H.F. Meyer, and R. Land (Eds.), Overcoming barriers to student understanding: Threshold concepts and troublesome knowledge (pp.3-18). London: Routledge Falmer.

Neumann, F., King, M., \& Carmichael, D.L. (2007). Authentic instruction and assessment. Common standards for rigor and relevance in teaching academic subjects. 
http://www.smallschoolsproject.org/PDFS/meetings/auth_instr_assess.pdf Accessed on 17 August 2012

Neumann, F.M., Marks, H.M., \& Gamoran, A. (1996). Authentic pedagogy and student performance. American Journal of Education, 104, 280-312.

Nicholls, G. (2005). The challenge to scholarship. Rethinking learning, teaching and research. New York: Routledge.

Nixon, J. (2011). Higher Education and the Public Good: Imagining the University. London and New York: Continuum International Publishing Group.

Nixon, J. (2008). Towards the virtuous university. The moral bases of academic practice. New York, NY: Routledge.

Nussbaum, M. (2011). Developing capabilities. Cambridge, New York: The Cambridge University Press.

Nussbaum, M. (2004). Upheavals of thought. Cambridge: Cambridge University Press.

Nussbaum, M. (2000). Women and human development. The capabilities approach. Cambridge: Cambridge University Press.

Nussbaum, M. (1997). Cultivating humanity: A classical defense of reform in liberal education. Cambridge, MA: Harvard University Press.

Nussbaum, M., \& Sen, A. (Eds.). (1993). The quality of life. Oxford: Clarendon Press.

Palmer, P. (1998). The courage to teach. San Francisco: Jossey-Bass.

Perkins, D. (2005). Theories of difficulty. Presentation at the British Journal of Educational Psychology Conference, The University of Edinburgh, 20 May, 2005.

Roxa, T., Olsson, T., \& Martensson, K. (2008). Appropriate use of theory in the scholarship of teaching and learning as a strategy for institutional development. Arts and Humanities in Higher Education, 7, 276-294

Shulman, L., Signature pedagogies of the professions. Dædalus, Summer 2005, pp. 52-59.

Shulman, L. (1987). Knowledge and teaching: Foundations of the new reform. Harvard Educational Review, 57(1), 1-22.

Splitter, L.J. (2009). Authenticity and constructivism in education. Studies in Philosophy and Education, 28(2), 135-151.

Svinicki M. (2005). Authentic assessment: testing in reality. New Directions for Teaching and Learning, 100, 23-29.

Taylor, C. (1991). The ethics of authenticity. Cambridge, MA: Harvard University Press.

Trigwell, K. , Martin, E. , Benjamin, J., \& Prosser, M. (2000). Scholarship of teaching and learning: A model. Higher Education Research and Development 19(2), 155-68.

Walker, M., \& McLean, M. (2013). Professional education, capabilities and contributions to the public good: The role of universities in promoting human development. London and New York: Routledge.

Walker, M (2010). A human development and capabilities 'prospective analysis' of global higher education policy. Journal of Education Policy, 25(4), 485-501. 
Walker, M. (2009). 'Making a world that is worth living in': Humanities teaching and the formation of practical reasoning. Arts and Humanities in Higher Education, 8(3), 231-246.

Walker. M. (2006). Higher education pedagogies. A capabilities approach. Maidenhead, Berkshire: The Society for Research into Higher Education and Open University Press.

Weimer, M. (1997). Assumptions that devalue university teaching. International Journal of Academic Development, 2(1), 52-59. 